wind of 80 miles an hour at an elevation of roo, 000 feet (less than the height deduced by Verbeek for that reached by some of the ejecta) might theoretically co-exist with a trade wind of ordinary velocity at the earth's surface.

It is not so much with reference to the velocity as to the direction of the upper currents near the equator that $\mathrm{Mr}$. Abercromby's itinerary observations are valuable, since they correspond both normally and exceptionally with what might be expected from the laws of aëro-dynamics. Theory is naturally perhaps, though still somewhat singularly, silent as to what is supposed to be the motion of the air in the upper regions of the belt bounded by $15^{\circ}$ on either side of the equator. Ferrel's equations are not very satisfactory for this space, owing to the smaliness of the term $2 v \omega \sin \theta$ representing the deflecting force of terrestrial rotation (ablenkungskraft), and close to the equator fail altogether at the surface. That the wind there, however, still maintains its westward component under the normal conditions which accompany the north and south trades is plain both from Mr. Abercromby's and other observations. Higher up, owing to the absence of friction, the air tends to move in the "inertia curve " corresponding to its motion at the surface, whose radius of curvature is $\frac{v}{2 \omega \sin \theta}$; and since near the equator $\sin \theta$ is very small this curve is very nearly a straight line parallel to the equator. Whatever therefore happens to the surface wind through local influences such as latitudinal shift of thermal equator or doldrums, or the establishment of a local heat maximum on a land surface causing a deflection of the normal trade wind into a lozal monsoon, ought not to interfere sensibly with the general tendcncy of the upper air to stream from east to west for a considerable space on either side of the equator. may just remark, en passant, that the belt bounded by $15^{\circ} \mathrm{N}$. and S. latitude embraces an area of more than one-quarter of the entire surface of the globe.

The apparent anomalies as well as rules exhibited by $\mathrm{Mr}$. Abercromby are thus seen to be in complete accordance with the above principle. It is only when we get some distance away from the equator that the gradient towards the poles in the upper atmosphere becomes large enough to change the westward into an eastward motion. As the air slides down this slope the radius of the "inertia curve" becomes smaller, and it veers through S.E. and S. to S.W., the normal direction of the upper current at the boundaries of the trade zones.

That the barometer gradient at a height of I3,000 feet over the equator is very small either from or towards the poles may be gathered from the following extract fron a table given by Dr. Sprung in his "Lehrbuch der Meteorologie" (Hamburg, 1885):-

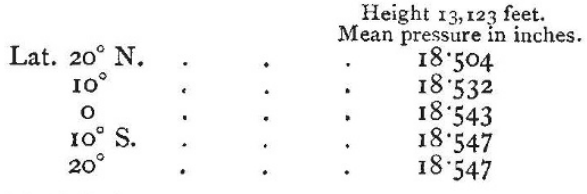

Above this height the gradient towards the poles would increase, but theoretically there might be no change in the direction of the wind near the equator.

June 3 .

E. Douglas Archibald.

\section{Mammaliferous Gravel at Elloughton, in the Humber Valley.}

I was informed a short time ago that a large bone had been found in a gravel-pit near Brough, on the Humber, and went at once to examine the place. I found the "bone" to be a mammoth's tusk of large size, and learnt that other teeth and bones had not infrequently been exhumed in the pit. As this seems to be a new locality for mammalian remains, I think a short description of the deposit may be found useful.

The excavation was commenced about twelve months ago on the top of a small isolated hill known as Mill Hill, which rises out of the Humber Flat to a height of about 90 feet, close to the village of Elloughton, and since that time there has been a constant and steady removal of the material, so that a good section is now exposed. The hill forms an outlier of the Wold Range, from which it is separated by low ground nearly a mile in width, the north shore of the Humber lying about one mile to the south of it. It is composed of Oolitic rocks overlain by gravel. The section at present shown is as follows :-

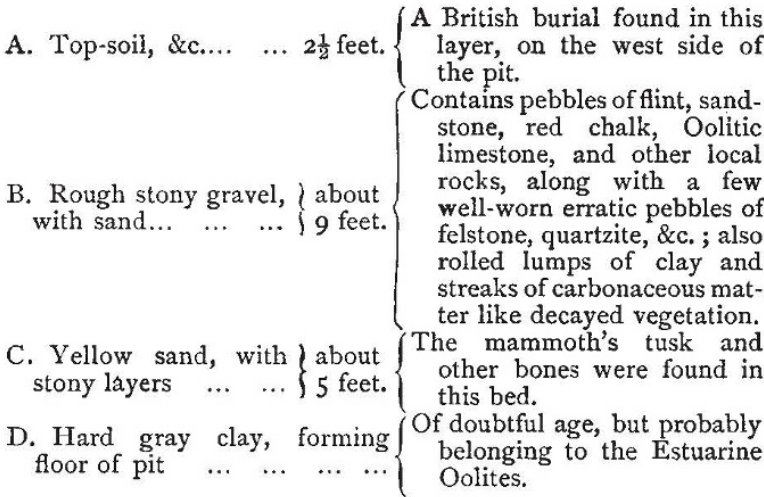

In the rough gravel, B, there are some boulders of local rocks so large as to suggest the idea that floating ice has been the agent of their transportation, especially as it seems as though the blocks must either have been raised from a lower level, or floated over the depression intervening between this hill and the Oolitic exposures in the flanks of the adjacent Wolds.

The junction of $\mathrm{B}$ with $\mathrm{C}$ is very well marked, and there are signs of erosion, and unconformity between them; but as the whole of the beds are current-bedded and irregular, this line of separation may be of no importance. On the other hand, since fossils seeni only to be found in the sand, $\mathrm{C}$, this may be the remains of an older deposit which has been denuded during the deposition of the overlying unfossiliferous gravel, B, and this latter bed may be a continuation of similar rough unfossiliferous gravels seen on the lower ground to the westward.

If the clay exposed on the bottom of the pit really forms part of the Oolites, I see no means of determining the age of these gravels; but my impression is that at any rate they are not older than the oldest boulder-clay of Holderness, and are probably not later than the newest. At Hessle, six miles to the eastward, bones have been found in a chalky rubble underlying boulderclay, which Prof. Phillips regarded as pre-Glacial. At Bielbecks, seven miles to the northward, similar remains were obtained in 1829 from a fresh-water deposit which I think was regarded as post-Glacial. It may be that these deposits will eventually prove all to be of one age.

The size and condition of the tusk were such that I do not think it can have been carried hither by water-currents alone. It has more probably either been dropped from the floating or living carcase of the animal or from a mass of floe-ice. Its length, as it lay exposed on the floor of the pit at the time of my visit, was 90 inches, but the workmen said they had broken up about two feet of the "thick end" before they were aware; and as the apex was also blunted and badly preserved, I think its length when first deposited cannot have fallen short of ro feet. Its diameter was 6 inches at a distance of ro inches from the apex; $7 \frac{1}{2}$ inches at 20 inches $; 8$ inches at $30 ; 8 \frac{1}{2}$ at 40 , beyond which it did not seem perceptibly to thicken. It lay in a water-logged gravel, and was in a very friable state; and though I was enabled, through the kindness of Mr. H. Lyon, the owner of the pit, to strengthen the specimen with cement, it crumbled into small splinters when an attempt was made to remove it, and was irretrievably ruined. Its curvature was not great, and would lie within a breadth of about 20 inches.

The only other remains I have yet obtained from the pit are some portions of the teeth of the mammoth and a few irrecognizable fragments of bone.

In the top-soil on the west side of the pit a British burial has been cut through, wherein lay the bones of a human skeleton, together with a fragmentary vase with the characteristic ornamentation.

Bridlington Quay, June 6.

G. W. Lamplugh.

Fall of Peculiar Hailstones in Kingston, Jamaica.

SHORTLY after midday on the and inst. a thunderstorm visited this city ; the rain began with the wind from the east, as is usual with our May seasons, but it speedily changed to the 